*ak FMIS View/Frint Document Cover Sheet tow

This document was retrieved from the Documentation and Records Manaqement (DRM) ISEARCH System. It is intended for Information only and may not be the most recent or updated version. Contact a Document Service Center (see Hanford Info for locations) if you need additional retrieval information.

Accession \#: D196069096

Document \#: SD-WM-DQO-024

Title/Desc:

DATA QUALITY OBJECTIVES FOR REGULATORY

REQUIREMENTS FOR WASTEWATER EFFLUENTS SAMPLING \& ANALYSIS

Pages: 49 


\begin{tabular}{|l|l|l|}
\hline $\begin{array}{l}\text { 2. To: (Receiving Organization) } \\
\text { Distribution }\end{array}$ & $\begin{array}{l}\text { 3. From: (Originating Organization) } \\
\text { Environmental Compliance and } \\
\text { Support Services }\end{array}$ & $\begin{array}{l}\text { 4. Related EDT No.: } \\
\text { N/A }\end{array}$ \\
\hline $\begin{array}{l}\text { 5. Proj./Prog./Dept./Div.: } \\
77550\end{array}$ & $\begin{array}{l}\text { 6. Cog. Engr.: } \\
\text { C.H. Mulkey }\end{array}$ & $\begin{array}{l}\text { 7. Purchase Order No.: } \\
\text { N/A }\end{array}$ \\
\hline $\begin{array}{l}\text { 8. Originator Renarks: } \\
\text { Sampling and analytical requirements relating to meeting } \\
\text { regulatory requirementg for measuring wastewater effluents. }\end{array}$ & $\begin{array}{c}\text { 9. Equip./Component No.: } \\
\text { N/A }\end{array}$ \\
\hline $\begin{array}{l}\text { 11. Receiver Remarks: } \\
\end{array}$ & $\begin{array}{c}\text { 12. Major Assm. Dwg. No.: } \\
\text { N/A } / A\end{array}$ \\
\hline
\end{tabular}

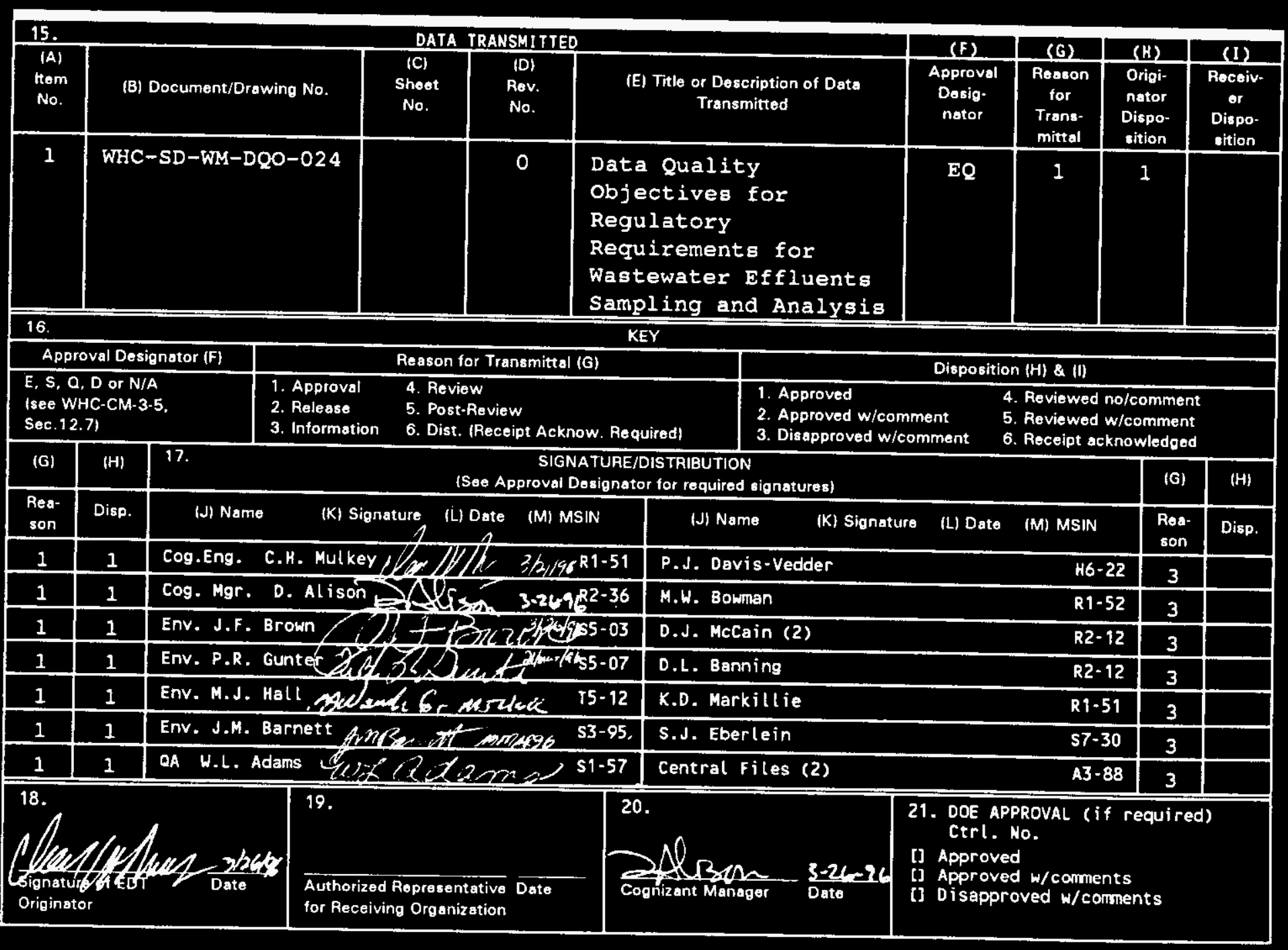




\title{
DATA QUALITY OBJECTIVES FOR REGULATORY REQUIREMENTS FOR WASTEWATER EFFLUENTS SAMPLING AND ANALYSIS
}

\author{
Mutusy, C.:A. \\ Weatinghouse Hanford Company, Richland, WA 99352 \\ U.S. Department of Energy Contract DE-AC06-87RL10930 \\ EDT/ECN: $613425 \quad$ UC: 2070 \\ Org Code: 77550 Charge Code: N1528 \\ B\&R Code: EW3120071 Total Pages: 446 \\ Key Words: Wastewater Effluents, DQO, Regulatory Requirements, Sampling \\ \& Analysis \\ Abstract: Contains requirements for wastewater effluent sampling which \\ are imposed by various federal and state regulations.
}

TRADEMARK DISCLAIMER. Reference herein to any specific comercial product, process, or service by trade name, trademark, manufacturer, or otherwise, does not necessarily constitute or inply its endorsement, recommendation, or favoring by the United States Government or any agency thereof or its contractors or subcontractors.

Printed in the United States of Anerica. To obtain copies of this document, contact: WHC/BCS Document Control Services, P.O. Box 1970, Mailstop H6-08, Richland WA 99352, Phone (509) 372-2420; Fax (509) 376-4989.
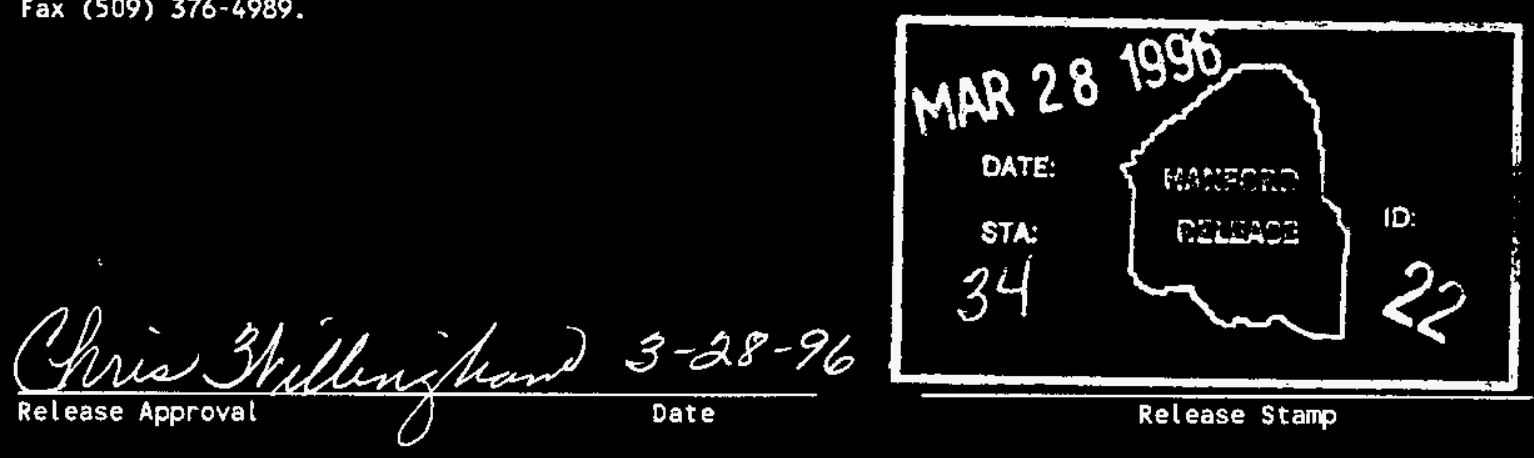

Approved for Public Release 


\section{DATA QUALITY OBJECTIVES \\ FOR REGULATORY \\ REQUIREMENTS FOR \\ WASTEWATER EFFLUENTS \\ SAMPLING AND ANALYSIS}

Charles H. Mulkey

Westinghouse Hanford Company

Kim D. Markillie

Stone \& Webster Engineering Corporation

Date Published

March 1996

Prepared for the U.S. Department of Energy

Office of Environmental Restoration and

Waste Management

Westinghouse P.O. Box 1970

Hanford Company Richland, Washington

Management and Operations Contractor for the U.S. Department of Energy under Contract DE-AC06-87RL10930

Approved for Public Release 
WHC-SD-WM-DQO-024 Rev. 0

This page intentionally left blank. 
WHC-SD-WM-DQO-024 Rev. 0

\section{CONTENTS}

1.0 INTRODUCTION AND PURPOSE $\ldots \ldots \ldots \ldots \ldots \ldots \ldots \ldots \ldots \ldots$. . . . . . . . . .

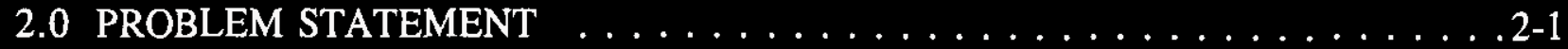

2.1 STAKEHOLDERS . . . . . . . . . . . . . . . . . 2-1

2.2 PLANNING TEAM MEMBERS $\ldots \ldots \ldots \ldots \ldots \ldots \ldots \ldots \ldots \ldots .2-1$

2.3 APPLICABILITY OF THIS DQO $\ldots \ldots \ldots \ldots \ldots \ldots \ldots \ldots . . \ldots \ldots$

3.0 DECISION IDENTIFICATION $\ldots \ldots \ldots \ldots \ldots \ldots \ldots \ldots \ldots \ldots \ldots \ldots \ldots$

3.1 WATER QUALITY STANDARDS FOR GROUND WATERS OF THE STATE OF WASHINGTON $\ldots \ldots \ldots \ldots \ldots \ldots \ldots$. . . . . . . . .

3.2 STATE WASTE DISCHARGE PERMIT PROGRAM (WAC 173-216) . . . . 3-2

3.3 UNDERGROUND INJECTION CONTROL PROGRAM (WAC 173-218) . . 3-5

3.4 TOXIC CHEMICAL RELEASE REPORTING (40 CFR 372) $\ldots \ldots \ldots$. . . .

3.5 RADIONUCLIDE REQUIREMENTS $\ldots \ldots \ldots \ldots$. . . . . . . . . .6

4.0 DECISION INPUTS $\ldots \ldots \ldots \ldots \ldots \ldots \ldots \ldots \ldots \ldots \ldots . . \ldots \ldots$

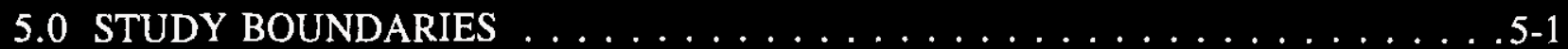

6.0 DECISION RULES $\ldots \ldots \ldots \ldots \ldots \ldots \ldots \ldots \ldots \ldots \ldots \ldots \ldots \ldots . . \ldots \ldots$

7.0 DECISION ERROR LIMITS $\ldots \ldots \ldots \ldots \ldots \ldots \ldots \ldots \ldots \ldots$. . . . . . . .

8.0 OPTIMIZATION OF SAMPLING AND ANALYSIS DESIGNS $\ldots \ldots \ldots \ldots$. . 8 - 1

8.1 NUMBER OF SAMPLES $\ldots \ldots \ldots \ldots \ldots \ldots \ldots$. . . . . . . . . . . . . .

8.2 SAMPLING AND ANALYSIS METHODS $\ldots \ldots \ldots \ldots \ldots \ldots$. . . . . .

8.2.1 Sample Handling and Analysis . . . . . . . . . . . 8-1

8.2 .2 Detection Limits $\ldots \ldots \ldots \ldots \ldots \ldots \ldots \ldots \ldots . \ldots \ldots$

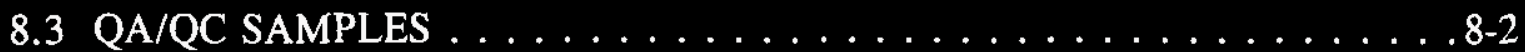

8.3.1 Trip Blanks . . . . . . . . . . . . . . . . 8-3

8.3.2 Duplicate Samples . . . . . . . . . . . . . . . . 8-3

8.3.3 Equipment Blanks . . . . . . . . . . . . . 8-3

9.0 REFERENCES . . . . . . . . . . . . . . . . . . . . . .9-1 
WHC-SD-WM-DQO-024 Rev. 0

\begin{abstract}
APPENDIX
REGULATORY DRIVERS OF POTENTIAL DISCHARGES . . . . . . . . . . A-1
\end{abstract}

\title{
LIST OF FIGURES
}

3-1. Decision Logic - Sample/Analysis Requirements . . . . . . . . . . . . . . . . 3-4

3-2. Decision Logic - Release of Toxic Chemicals . . . . . . . . . . . . . . . . . . 3-7

\section{LIST OF TABLES}

1-1. Summary of Regulations Reviewed for Wastewater DQO $\ldots \ldots \ldots \ldots$. . . . . . . .

5-1. Inventory of Streams Under the Jurisdiction of TWRS . . . . . . . . . . . 5-2

6-1. Indicator Pollutants for Wastewater Discharges . . . . . . . . . . . . 6-1

A-1. Regulatory Drivers of Potential Wastewater Discharges $\ldots \ldots \ldots \ldots \ldots$. . . . . 
WHC-SD-WM-DQO-024 Rev. 0

\section{LIST OF TERMS}

CFR

DOE

DQO

Ecology

EPA

EPCRA

ETF

QA/QC

QAPP

SOW

TEDF

TWRS

WAC

WHC
Code of Federal Regulations

U.S. Department of Energy

data quality objective

Washington State Department of Ecology

Environmental Protection Agency

Emergency Planning and Community Right-to-Know Act of 1986

Effluent Treatment Facility

quality assurance/quality control

quality assurance project plan

Statement of Work

Treated Effluent Disposal Facility

Tank Waste Remediation System

Washington Administrative Code

Westinghouse Hanford Company 


\section{GLOSSARY}

Direct discharge: Any direct addition of any pollutant or combination of pollutants to surface waters of the state or to waters of the contiguous zone from any point source, excluding those waste streams that are discharged to a storage or disposal facility. [Modification to WAC 173-226-030(6)]

Discharge:

The addition of any pollutant or combination of pollutants to waters of the state [WAC 173-226-030(6)]; where "Waters of the state" means all lakes, rivers, ponds, streams, inland waters, ground waters, salt waters, and all other waters and water courses within the jurisdiction of the state of Washington. [WAC 173-216-030(20)]

Effluent stream: A liquid or semi-solid discharge of waste flowing to a treatment or disposal unit.

Ground water: Water in a saturated zone or stratum beneath the surface of land or below a surface water body. [WAC 173-200-020(12)]

Monitor:

An ongoing program used to sample and report the concentration of contaminants contained in a liquid effluent stream and designed to account for variations in the processes or operations that generate the effluents.

Release: $\quad$ Any spilling, leaking, pumping, pouring, emitting, emptying, discharging, injecting, escaping, leaching, dumping, or disposing into the environment (including the abandonment or discarding of barrels, containers, and other closed receptacles) of any toxic chemical. (40 CFR 372.3)

Wastewater: Water or liquid-carried waste from industrial or commercial processes, as distinct from domestic wastewater. These waste may result from any process or activity of industry, manufacture, trade or business, from the development of any natural resource, or from animal operation such as feed lots, poultry houses, or dairies. The term includes contaminated stormwater and, also, leachate from solid waste facilities. [WAC 173-216-030(8)] 


\subsection{INTRODUCTION AND PURPOSE}

This data quality objective (DQO) was developed using the Tank Waste Remediation Systems (TWRS) Data Quality Objective Procedure, WHC-IP-1216 (Banning 1996) which is based on the U.S, Environmental Protection Agency (EPA) DQO guidelines (EPA 1994). This DQO identifies state and federal regulatory requirements associated with sampling and analysis of effluents under the jurisdiction of TWRS.

The policy of the U.S. Department of Energy (DOE) is to conduct operations in a safe, costeffective, and environmentally sound manner and to ensure that discharges of radioactive and nonradioactive materials to the environment meet applicable regulatory requirements.

Users of this document will find a summary of required analyses in Section 8.0. A brief description of each covered regulatory driver is incorporated into Section 3.0. Regulatory requirements are expected to change as permits are issued and regulations are modified. This document should not be used for determining overall compliance with regulations as the regulations are in constant change. However, this document does reflect the latest regulatory requirements at the date of publication.

Several federal and state laws and regulations require the reporting of wastewater effluents or establish wastewater effluent limits. These regulations also require that changes to wastewater effluents be determined whenever existing equipment is modified or the installation of new equipment is planned. In some cases, the use of calculated effluent rates or modelling of effluents may be used instead of requiring actual analytical data. In most instances where effluent calculations or modelling is allowed, it is still a best management practice to validate the calculated effluent rates with actual measurements.

The purpose of this DQO is to identify current data needs for complying with regulatory drivers for the sampling and analysis of wastewater effluents from TWRS facilities. These drivers include regulatory requirements and best management practices. Note that analyses may have more than one regulatory driver. The data needs to include sampling requirements for both radionuclide and non-radionuclide analytes from facility wastewater effluents. Unless specified differently, it is intended that this DQO not be a driver in determining the sampling schedule. The analyses required by this document should be incorporated into any sampling and analytical plan for any of the specified TWRS facilities. Stormwater discharges that are not registered as an underground injection well and one-time discharges are not addressed in this document.

The Department of Ecology (Ecology) Consent Order No. DE 91NM-177 (Ecology 1991), lists regulatory milestones for effluent streams at the Hanford site that require compliance with permitting requirements of Washington Administrative Codes (WACs) where applicable. The Consent Order has set a plan and schedule for disposition and regulatory compliance for wastewater effluent streams permitting, sampling/analyzing, and monitoring that will be 
performed as required by individual or categorical permits as they are issued. When these permits are issued, they may contain additional analytical requirements.

The regulations that were reviewed for this DQO process are summarized in Table 1-1 . This table summarizes the regulations, applicability of each regulation, and any comments regarding the reason for exclusion. The applicability of the regulations was determined based on current TWRS activities and discharges. If these activities change, some of these regulations may become applicable. Each regulatory driver which is applicable is discussed in a separate subsection in Section 3.0. 
Table 1-1. Summary of Regulations Reviewed for Wastewater DQO. (3 Sheets)

\begin{tabular}{|c|c|c|c|}
\hline \multicolumn{2}{|c|}{ Regunarory ifuress } & \multirow{2}{*}{ 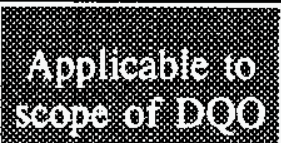 } & \multirow[b]{2}{*}{ corringnings: } \\
\hline 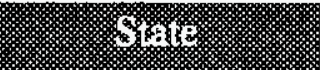 & 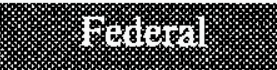 & & \\
\hline WAC $173-14,20$ & N/A & No & $\begin{array}{l}\text { Discharges on shorelines are not being } \\
\text { performed, therefore these regulations do } \\
\text { not apply. }\end{array}$ \\
\hline WAC $173-200$ & N/A & Yes & $\begin{array}{l}\text { Analytical requirements may be necessary } \\
\text { in order to prove contaminants are not } \\
\text { above the primary or secondary ground } \\
\text { water contaminant levels. }\end{array}$ \\
\hline WAC 173-201A & 40 CFR 122 & No & $\begin{array}{l}\text { Discharges directly to the Columbia river } \\
\text { are not being performed, therefore this } \\
\text { regulations does not apply. }\end{array}$ \\
\hline WAC $173-216$ & N/A & Yes & $\begin{array}{l}\text { Monitoring requirements for wastewater } \\
\text { discharges. Applicable to one-time and } \\
\text { continuous discharges of wastewater to } \\
\text { ground and surface waters. Permit } \\
\text { application requires analytical information } \\
\text { for compounds listed in Table A-1. }\end{array}$ \\
\hline WAC $173-218$ & $\begin{array}{l}40 \text { CFR 144, } \\
146,148,10 \\
\text { CFR } 20\end{array}$ & Yes & $\begin{array}{l}\text { Subsurface discharge requirements for } \\
\text { UICs which applies to the injection of } \\
\text { fluids through wells. }\end{array}$ \\
\hline WAC $173-220$ & N/A & No & $\begin{array}{l}\text { NPDES permit program requirements are } \\
\text { not applicable, therefore this regulation } \\
\text { does not apply. }\end{array}$ \\
\hline WAC $173-221$ & N/A & No & $\begin{array}{l}\text { This regulation pertains to effluents from } \\
\text { domestic wastewater treatment plants, } \\
\text { therefore it does not apply. }\end{array}$ \\
\hline WAC $173-225$ & $\begin{array}{l}\text { Section } 401 \text { of } \\
\text { FWPCA }\end{array}$ & No & $\begin{array}{l}\text { Federal Water Pollution Control Act } \\
\text { requirements are not applicable. }\end{array}$ \\
\hline WAC $173-226$ & N/A & No & $\begin{array}{l}\text { Permit applications pursuant to WAC } 173- \\
216 / 218 \text { will be submitted per Consent } \\
\text { Order DE } 91 \mathrm{NM}-177 \text {, in place of the } \\
\text { general permitting via this regulation. }\end{array}$ \\
\hline WAC $173-230$ & N/A & No & $\begin{array}{l}\text { Construction of a wastewater facility is } \\
\text { not being performed, therefore } \\
\text { certification of operators is not applicable. }\end{array}$ \\
\hline
\end{tabular}


Table 1-1. Summary of Regulations Reviewed for Wastewater DQO. (3 Sheets)

\begin{tabular}{|c|c|c|c|}
\hline \multicolumn{2}{|c|}{ 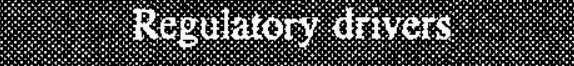 } & \multirow{2}{*}{ 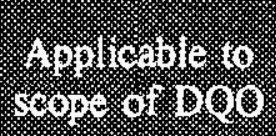 } & \multirow[b]{2}{*}{ 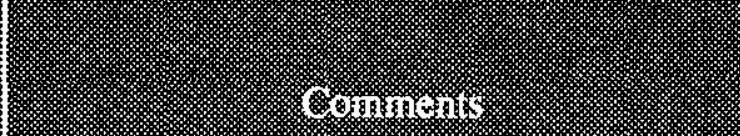 } \\
\hline singe & forigral & & \\
\hline WAC $173-240$ & N/A & No & $\begin{array}{l}\text { Construction of wastewater facility is not } \\
\text { being performed, therefore this regulation } \\
\text { is not applicable. }\end{array}$ \\
\hline WAC $173-303$ & N/A & No & $\begin{array}{l}\text { This regulation will be addressed in the } \\
\text { TWRS dangerous waste DQO process for } \\
\text { any dangerous/hazardous emissions. }\end{array}$ \\
\hline WAC 173-304 & N/A & No & $\begin{array}{l}\text { Minimum functional standards for solid } \\
\text { waste handling is not applicable to the } \\
\text { scope of this document. }\end{array}$ \\
\hline WAC $173-340$ & N/A & No & $\begin{array}{l}\text { Releases or threatened releases are to be } \\
\text { covered by } 40 \text { CFR } 372 \text { in place of } \\
\text { release reporting via this regulation. }\end{array}$ \\
\hline WAC $246-272$ & N/A & No & $\begin{array}{l}\text { No TWRS unit produces more than } \\
14,500 \text { gallons of waste per day. } \\
\text { Therefore, requirements for new facilities } \\
\text { and sanitary sewerage discharges are not } \\
\text { applicable. }\end{array}$ \\
\hline WAC $246-290$ & N/A & No & $\begin{array}{l}\text { Drinking water supply system } \\
\text { requirements are not applicable to this } \\
\text { document. }\end{array}$ \\
\hline $\begin{array}{l}\text { Consent Order } \\
\text { DE } 91 \mathrm{NM}-177\end{array}$ & N/A & Yes & $\begin{array}{l}\text { Development of sampling and analysis } \\
\text { plans and schedules for permitting } \\
\text { wastewater streams. 242-A Evaporator } \\
\text { and 222-S Laboratory sample analysis } \\
\text { plans have been issued and require } \\
\text { confirmatory analysis of the wastewater. }\end{array}$ \\
\hline N/A & 40 CFR 117 & No & $\begin{array}{l}\text { Determination of reportable quantities for } \\
\text { hazardous substances has been } \\
\text { incorporated in } 40 \text { CFR } 372 \text { in place of } \\
\text { this regulation. }\end{array}$ \\
\hline N/A & 40 CFR 136 & No & $\begin{array}{l}\text { Test procedures for the analysis of } \\
\text { pollutants are covered by other analytical } \\
\text { sources in place of this regulation. }\end{array}$ \\
\hline
\end{tabular}


Table 1-1. Summary of Regulations Reviewed for Wastewater DQO. (3 Sheets)

\begin{tabular}{|c|c|c|c|l|}
\hline N/A & $\begin{array}{c}40 \text { CFR 141, } \\
143\end{array}$ & No & $\begin{array}{l}\text { National primary and secondary water } \\
\text { contaminant regulations has been } \\
\text { incorporated in WAC 173-200 in place of } \\
\text { this regulation. }\end{array}$ \\
\hline N/A & 40 CFR 372 & Yes & $\begin{array}{l}\text { Spills and discharges into the environment } \\
\text { and thresholds for reporting releases to the } \\
\text { environment addressed. }\end{array}$ \\
\hline N/A & $\begin{array}{c}\text { 10 CFR 834 } \\
\text { (Proposed) }\end{array}$ & No & $\begin{array}{l}\text { Radiation protection to the public and the } \\
\text { environment is therefore covered by best } \\
\text { management practices established by DOE } \\
\text { Orders which mandate effluent levels and } \\
\text { controls of radionuclides. This regulation } \\
\text { is proposed but is expected to be finalized } \\
\text { before June 1996. }\end{array}$ \\
\hline
\end{tabular}


WHC-SD-WM-DQO-024 Rev. 0

This page intentionally left blank. 


\subsection{PROBLEM STATEMENT}

This DQO (WHC-SD-DQO-024) identifies wastewater sampling and analysis requirements for the TWRS facilities which are needed to address environmental regulatory needs. The specific regulatory drivers for wastewater effluents are listed in Table 1-1.

This document identifies the environmental regulatory drivers for wastewater sampling, states when analysis should be obtained, and identifies the facilities where sampling or monitoring is required or should be conducted. It also identifies specific analytes and QA/QC procedures and effluent limits.

\subsection{STAKEHOLDERS}

The major programs which might be impacted by the results of this DQO are: East and West Tank Farm Transition Projects, Evaporator Project, Environmental Cleanup and Compliance Project, Characterization Project, 222S Laboratory, 200 Area Treated Effluent Disposal Facility (TEDF), the 200 Area Effluent Treatment Facility (ETF), and Kaiser Engineering Hanford construction projects.

\subsection{PLANNING TEAM MEMBERS}

The following list of personnel have been identified as planning team members for this DQO process. They are: Dave Banning (WHC), Mark Bowman (WHC), Paula Davis-Vedder (WHC), Mike Hall (WHC), Kristi Lueck (WHC), Kim Markillie (SWEC), and Chuck Mulkey (WHC).

\subsection{APPLICABILITY OF THIS DQO}

This DQO is applicable to all equipment, facilities and operations under the jurisdiction of TWRS which discharge or have the potential to discharge wastewater, as defined by WAC 173-216-030 (see glossary). See Section 5.0 for specified effluent sources. 
WHC-SD-WM-DQO-024 Rev. 0

This page intentionally left blank. 
WHC-SD-WM-DQO-024 Rev. 0

\subsection{DECISION IDENTIFICATION}

Environmental regulatory drivers for sampling and analyzing wastewater effluents from TWRS facilities need to be identified in order to ensure that characterization efforts are being performed in compliance with regulations. The TWRS DQO process clearly states that stakeholders address three key questions: (1) What data is required to answer the question posed; (2) Why is new data required; and (3) How will the newly obtained data be used to answer the posed question.

If the answers to these questions justify the need for new data, then appropriate sampling and analysis documentation would be created and implemented. If the answers to these questions do not support a data collection effort, then important time and money savings from not doing needless sampling and analysis has been accomplished.

The decision which needs to be made is whether or not sampling and analysis of a particular wastewater stream is required and/or desired in order to meet regulatory requirements for wastewater effluents from TWRS facilities. Effluents may need to be quantified or estimated for reporting discharges to regulatory agencies, to determine compliance with effluent standards, or to determine if a specific environmental requirement applies to the effluent point. TWRS is only required to quantify effluents in certain instances. In many instances, analysis is not required but is a best management practice used to confirm that a waste's composition has not changed, or to prepare for a future activity which will require a determination of effluent changes.

Each of the following sections addresses a specific regulatory issue. An issue contains a short description and a requirement section. The results have been written as a decision statement. Regulations guiding dangerous waste requirements, will not be addressed in this DQO process but an additional DQO which will be submitted at a later date. The implementation of the decision statements for each type of wastewater stream has been used to produce the sampling and analysis designs in Section 8.0.

\subsection{WATER QUALITY STANDARDS FOR GROUND WATERS OF THE STATE OF WASHINGTON (WAC 173-200)}

Washington Administrative Code 173-200 applies to all ground waters of the state that occur in a saturated zone or stratum beneath the surface of land or below a surface water body. The purpose of this regulation is to establish minimum requirements for evaluating the impacts of an activity on the ground water quality. This regulation requires adherence to any conditions which are part of the permits for discharges required by WAC 173-216 and 218 .

The following decision logic should be followed to determine whether sampling and analysis information should be obtained to support WAC 173-200. Decision steps are organized by 
priority and in the most logical and efficient sequence for analyzing and solving the problem. A flowchart of the decision logic is shown in Figure 3-1.

\section{Decision Logic}

Requirement: $\quad$ Determine if any sampling and analysis needs to be implemented for any wastewater effluent streams.

1. Determine if a state waste discharge permit has been issued per WAC 173-216 or 218 which covers the wastewater effluent.

2. Determine if any permit contains sampling/analysis requirements for conditions pertaining to a state waste discharge permit.

3. Determine if data is available to meet the analytical requirements identified in $\# 2$.

4. Determine if a permit is required for a specific wastewater discharge.

\section{Results:}

1. If a state waste discharge permit has been issued and special conditions exist, follow the special conditions of the permit.

2. If no special conditions in the permit exist, no sampling or analysis is required.

3. If a permit is not required, no sampling or analysis is needed.

4. If it is determined that no existing permits cover a specific wastewater stream, it may be necessary to apply for an individual permit, which could potentially require specific sampling and analysis for the permit application. See Table A-1 in the appendix for specific analyses.

\subsection{STATE WASTE DISCHARGE PERMIT PROGRAM (WAC 173-216)}

The purpose of WAC $173-216$ is to implement a state permit program, applicable to one-time and continuous discharges of waste materials from industrial, commercial, and municipal operations into ground and surface waters of the state and into municipal sewerage systems.

Any permit issued by Ecology is required to specify any conditions which are necessary to prevent degradation to waters of the state. Whenever appropriate, Ecology will specify conditions which include monitoring, reporting and record keeping requirements. 
The following decision logic should be followed to determine whether sampling and analysis information should be obtained to support the state waste discharge permit program. A flowchart of the decision logic is summarized in Figure 3-1.

\section{Decision Logic}

Requirement: Determine if sampling or analysis is required for any wastewater effluent stream.

1. Determine if a state waste discharge permit has been issued for a specific wastewater effluent stream.

2. Determine if a wastewater discharge permit is required for a stream.

3. For a stream which requires a permit, determine if the individual or categorical wastewater discharge permit for an effluent stream or group of streams has any specified conditions for sampling and analysis.

4. Determine if conditions in the permit have already been met.

\section{Result:}

1. If a permit has not been issued, sampling/analysis to meet permit conditions is not required. It is advisable to determine the applicability of the existing permits and apply for a permit if required.

2. If a permit is required for the stream, obtain characterization information and submit a wastewater discharge permit application.

3. If a permit has been issued and no sampling/analysis conditions are specified by the discharge permit, sampling/analysis is not required.

4. If analytical data or documentation as conditioned in the permit is not available, sample/analyze according to permit requirements. 
WHC-SD-WM-DQO-024 Rev. 0

Figure 3-1. Decision Logic - Sample/Analysis Requirements for Wastewater Streams.

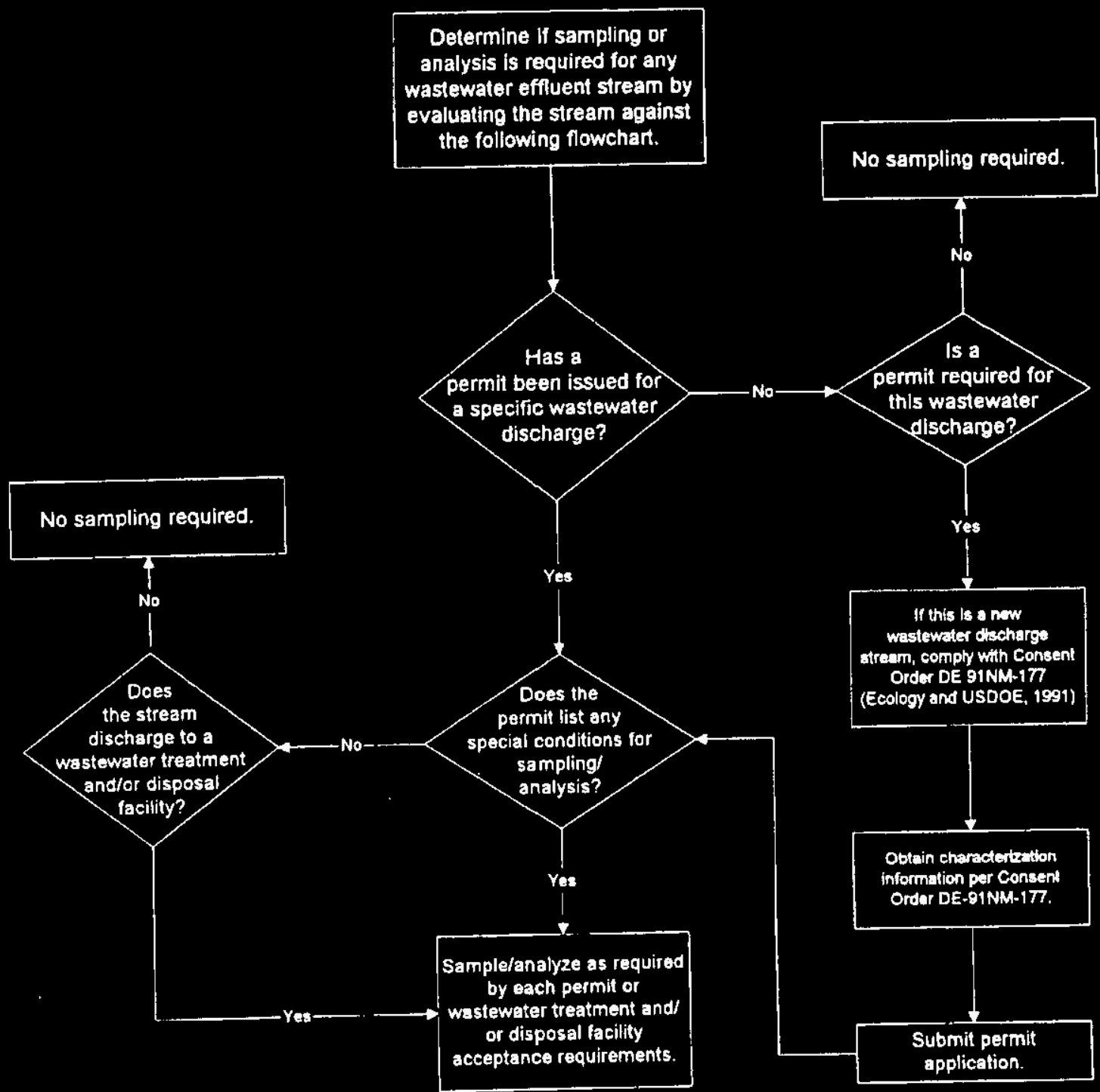




\subsection{UNDERGROUND INJECTION CONTROL PROGRAM (WAC 173-218)}

The purpose of WAC 173-218 is to set forth the procedures and practices applicable to the injection of fluids through wells. Permits issued in accordance with the provisions of this chapter are designed to satisfy the intent and requirements of the Safe Drinking Water Act and of the Water Pollution Control Act and to preserve and protect ground waters, including underground sources of drinking water, for existing and future beneficial uses. Per Consent Order DE 91NM-177 (Ecology and USDOE 1991) and the Plan and Schedule for Disposition and Regulatory Compliance for Miscellaneous Streams (DOE 1994), TWRS will not be submitting any permits per WAC 173-218. However, TWRS will be registering underground injection wells per this requirement by permitting the wells through WAC 173216. Further discussion of the consent order is contained in section 5.0 of this document.

Any permit issued by Ecology is required to specify any conditions which are necessary to prevent degradation to waters of the state. This shall include, whenever applicable, all known, available, and reasonable methods of prevention, control, and treatment; and any conditions necessary to preserve and protect underground sources of drinking water.

The decision logic in Section 3.2 should be followed to determine whether sampling and analysis information should be obtained to support the underground injection control program. A flowchart of the decision logic is summarized in Figure 3-1.

\subsection{TOXIC CHEMICAL RELEASE REPORTING (40 CFR 372)}

Section 313 of the Emergency Planning and Community Right-to-Know Act (EPCRA) requires reporting certain routine and nonroutine chemical releases (as defined in the glossary) when they exceed a specified threshold. Releases from each facility are aggregated to determine whether a threshold has been exceeded. Because the Hanford Site is considered one facility, release thresholds could be exceeded by the numerous units releasing relatively small amounts of the same chemical. This makes it necessary to track even very low levels of specified chemicals.

EPCRA does not require additional monitoring or measurement of the quantities or concentrations of any toxic chemical beyond that required by other laws or regulations, but it does require that releases over a certain threshold be reported and quantified. This quantification does not have to be based on analysis; but can use other methods such as calculations.

The following decision logic should be followed to determine whether additional information should be obtained to support the toxic chemical release reporting program. A flowchart of the decision logic is summarized in Figure 3-2. 


\section{Decision Logic}

Requirement: Determine whether additional information should be obtained to support the reporting required by EPCRA (40 CFR 372, Part 65).

1. From each effluent unit, evaluate adequacy of engineering calculations and available data for quantifying discharges of compounds listed in Table A-1.

2. If necessary, obtain analytical data for compounds suspected of being discharged in excess of threshold limits.

Results:

1. If chemical releases can be accurately estimated using existing data, sampling may not be required.

2. If analytical data or documentation is not available, obtain sufficient information on each appropriate chemical so that effluent data can be calculated. Information obtained by sampling/analysis is preferred, but it may be obtained by engineering estimates, mass balances, or other means.

\subsection{RADIONUCLIDE REQUIREMENTS}

Radionuclide requirements are addressed in this document via best management practices established by DOE Orders that are currently in the process of becoming federal regulations (10 CFR 834). This order is expected to be incorporated into federal regulation starting in April 1996. However, because DOE Orders are currently not regulations but are specific site management documents, they will not be explicitly addressed in this document. Radionuclide effluent sampling/analysis requirements for Table A-1 (Appendix A), were adopted from WAC 173-200 in accordance with the 200 Area TEDF state waste discharge permit that was issued (Ecology 1995a). Through this permit, Ecology determined that the Hanford site will be self-regulating for radioactive contaminants under the provisions of the Atomic Energy Act. The facility plans to meet the intent of 40 CFR Part 141, "National Primary Drinking Water Regulations" in regards to radioactive contaminants; and plans to take investigative and mitigative steps if drinking water standards are exceeded. 
Figure 3-2. Decision Logic - Release of Toxic Chemicals.

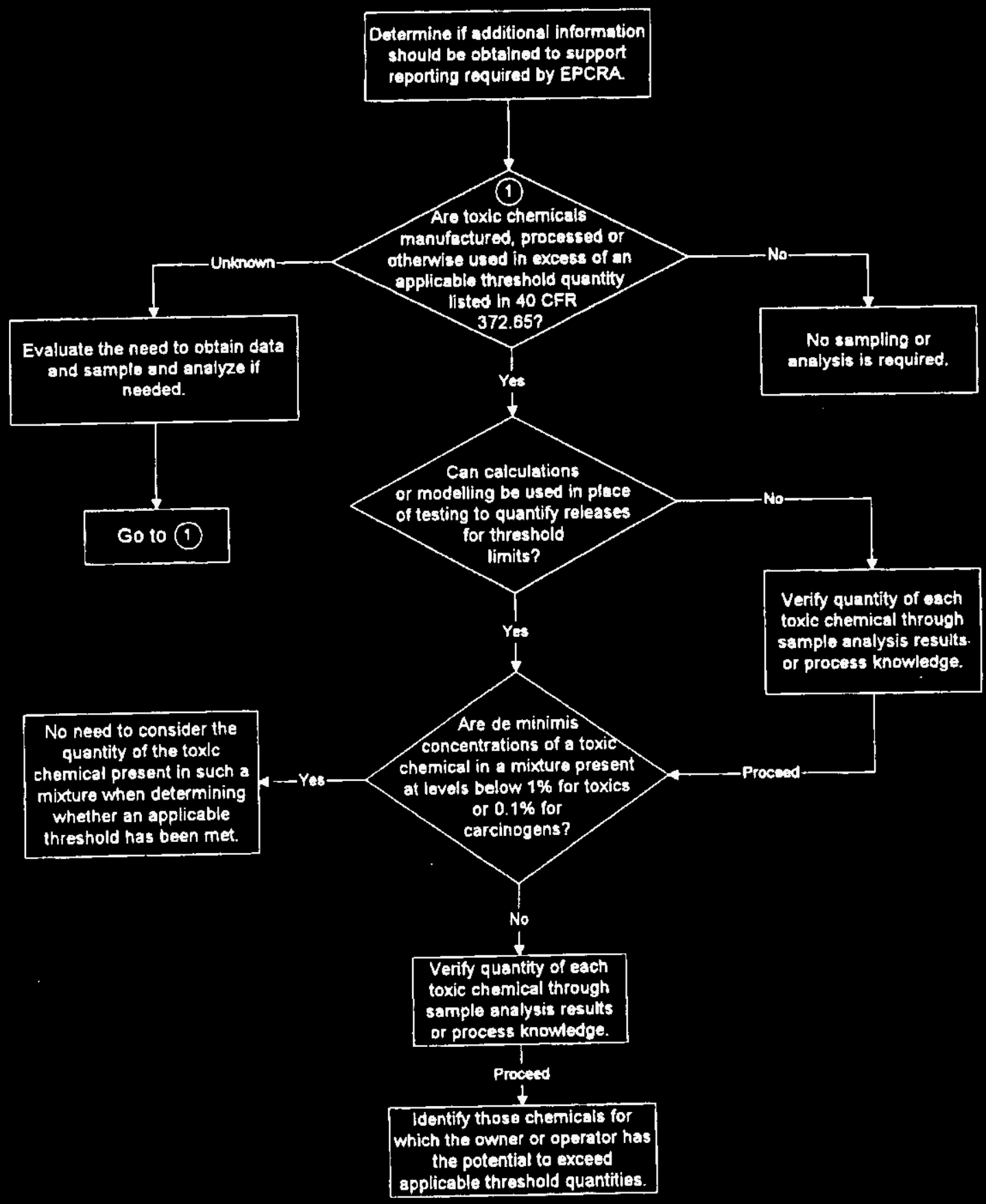


WHC-SD-WM-DQO-024 Rev. 0

This page intentionally left blank. 
WHC-SD-WM-DQO-024 Rev. 0

\subsection{DECISION INPUTS}

The decision inputs are the regulations identified in Section 3.0, in addition to the State waste discharge permits for the 200 Area TEDF and ETF (Ecology 1995a and 1995b), and the Interface Control Document for the 200 Area TEDF facility (WHC 1994). 
WHC-SD-WM-DQO-024 Rev. 0

This page intentionally left blank. 


\subsection{STUDY BOUNDARIES}

The scope of this document covers all TWRS units that discharge or have the potential to discharge wastewater pollutants to the ground or surrounding surface waters. Liquid effluent streams from these units at the Hanford site were categorized into Phase I streams, Phase II streams, and Miscellaneous streams, based on compositional and flow rate characteristics.

Consent Order DE 91NM-177 (Ecology and USDOE 1991) provides compliance milestones for wastewater streams. A plan which includes an overall regulatory strategy, methodology, and schedule for identification and evaluation of all miscellaneous streams has been published. This document (DOE 1994) and the consent order set certain regulatory milestones for complying with: permitting requirements under WAC 173-216/218; sampling and analysis plans; construction schedules; impact assessments; and interim operating instructions. Facility interface control documents, waste analysis plans or waste acceptance criteria will all specify sampling/analysis requirements for waste being received at specific treatment, storage or disposal facilities.

Table 5-1 lists all the streams, Phase I and II and the Miscellaneous streams, that are covered by this DQO process. Numerous documents exist which give a status of where these streams are in the permitting process. Those documents include the consent order and the Plan and Schedule for Disposition and Regulatory Compliance of Miscellaneous Streams (DOE 1994), among others. These documents may be amended on a yearly basis and should be referred to for the most up-to-date information concerning the permitting strategy and status. 
WHC-SD-WM-DQO-024 Rev. 0

Table 5-1. Inventory of Streams Under the Jurisdiction of TWRS. (2 Sheets)

\begin{tabular}{|c|c|c|}
\hline 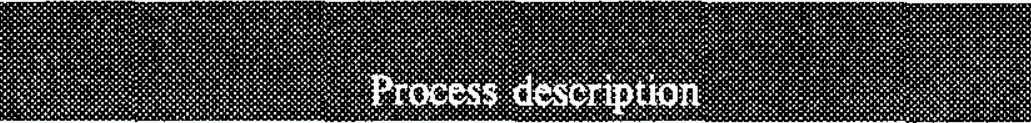 & intromis & iernints: \\
\hline \multicolumn{3}{|l|}{ i. il. } \\
\hline 222-S Laboratory Wastewater & N/A & 216 \\
\hline $\begin{array}{l}\text { 242-A-81 Water Services Building (PUREX Chemical } \\
\text { Sewer) }\end{array}$ & N/A & 216 \\
\hline \multicolumn{3}{|l|}{ Phase II Surearis } \\
\hline 242-A Evaporator Cooling Water & N/A & 216 \\
\hline $\begin{array}{l}\text { 241-A Tank Farm Cooling Water (Will be replaced with } \\
\text { Project W-030, new AY/AZ Vent System Cooling Tower } \\
\text { Discharge) }\end{array}$ & N/A & 216 \\
\hline 244-AR Vault Cooling Water & N/A & 216 \\
\hline 242-A Evaporator Steam Condensate & N/A & 216 \\
\hline \multicolumn{3}{|l|}{ 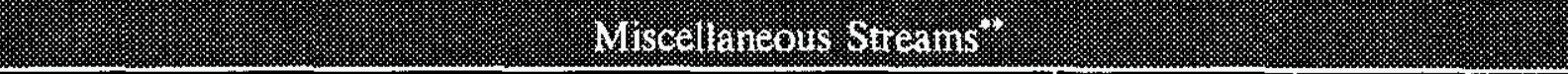 } \\
\hline 222-S Building Steam Condensate & 200 & 218 \\
\hline 222-S Building Catch Basin & 203 & $216 / 218$ \\
\hline 222-S Building Catch Basin \#01 & 204 & $216 / 218$ \\
\hline 222-S Building Catch Basin \#02 & 205 & $216 / 218$ \\
\hline 222-S Building Catch Basin \#03 & 206 & $216 / 218$ \\
\hline 222-S Building Catch Basin \#04 & 207 & $216 / 218$ \\
\hline 222-S Building Catch Basin \#05 & 208 & $216 / 218$ \\
\hline 222-S Building Catch Basin \#06 & 209 & $216 / 218$ \\
\hline 222-S Building Catch Basin \#07 & 210 & $216 / 218$ \\
\hline 222-S Building Catch Basin \#08 & 211 & $216 / 218$ \\
\hline 222-S Building Catch Basin \#10 & 212 & $216 / 218$ \\
\hline 222-S Building Catch Basin \#11 & 213 & $216 / 218$ \\
\hline 222-S Building Catch Basin \#12 & 214 & $216 / 218$ \\
\hline 222-S Building Catch Basin \#13 & 215 & $216 / 218$ \\
\hline
\end{tabular}


Table 5-1. Inventory of Streams Under the Jurisdiction of TWRS. (2 Sheets)

\begin{tabular}{|c|c|c|}
\hline 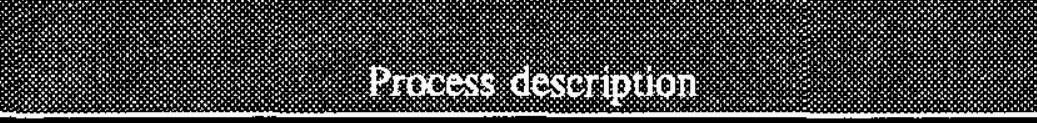 & Sirroariti: & 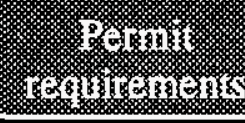 \\
\hline 222-S Building Catch Basin \#16 & 216 & $216 / 218$ \\
\hline 222-S Building Catch Basin & 217 & $216 / 218$ \\
\hline 241A Tank Farm Steam Condensate & 219 & 218 \\
\hline 241A Tank Farm Steam Condensate & 220 & 218 \\
\hline $\begin{array}{l}\text { DACS Trailer (supporting 101-SY) - Condensate from } 10 \\
\text { ton HVAC unit }\end{array}$ & 468 & 218 \\
\hline $\begin{array}{l}\text { 242-A-2, 242-A-3, 242-A-4 Steam Traps and Relief Valve } \\
\text { PSV-EA1-1 }\end{array}$ & 547 & 218 \\
\hline 222S Building Steam Condensate & 576 & 218 \\
\hline $\begin{array}{l}\text { 222S Building injection well receives overflow storm } \\
\text { water from stream numbers } 212,216 \text {, and } 217\end{array}$ & 581 & $216 / 218$ \\
\hline $\begin{array}{l}\text { 222S Building drain line collects overflow storm water } \\
\text { from stream numbers } 209 \text { and } 211\end{array}$ & 584 & 216 \\
\hline $\begin{array}{l}\text { 222S Building gravel filled drainage pit collects overflow } \\
\text { storm water from stream numbers } 203 \text { and } 215\end{array}$ & 586 & 216 \\
\hline $\begin{array}{l}\text { Any new discharges not currently identified, not sampled } \\
\text { previously, with uncertain process knowledge, or any with } \\
\text { compositional changes which are unknown }\end{array}$ & TBD & TBD \\
\hline
\end{tabular}

Notes:

N/A $=$ Not Applicable

$\mathrm{TBD}=$ To Be Determined

$216=$ Permitting under WAC 173-216

$218=$ Registration under WAC 173-218

* = Phase I and II streams defined in Consent Order DE 91NM-177 (Ecology and USDOE, 1991)

** = Miscellaneous streams are listed in the Inventory of Miscellaneous Streams report (DOE, 1995). 
WHC-SD-WM-DQO-024 Rev. 0

This page intentionally left blank. 


\subsection{DECISION RULES}

Decision rules for needed analyses were formed by applying the regulatory drivers discussed in Section 3.0 to the units subject to these requirements such as new streams, unsampled streams, streams with unknown changes in composition, and streams with uncertain process knowledge (described in Section 5.0). The rules are based on the combination of best management practice and specific regulatory requirements.

\section{Decision Rules}

The following Decision Rules were used in determining analytical requirements in the DQO:

1. If an analytical requirement was specified by a regulation or permit condition, then that requirement must be met.

2. If a discharge which has not been permitted continues over an extended period of time and there is no knowledge of the stream being discontinued or rerouted, then evaluate the process knowledge of the stream, for any compositional change.

3. If a stream appears to have changed in composition from the evaluation, perform sampling/analysis requirements for indicator pollutants in Table 6-1.

4. If characterization results from the indicator pollutants display any evidence that the wastewater stream has changed in composition, then evaluate what pollutants would have caused the change and sample/analyze as needed.

Table 6-1. Indicator Pollutants for Wastewater Discharges.

\begin{tabular}{|l||}
\hline Parameter \\
\hline pH \\
Conductivity \\
Total Dissolved Solids \\
Chemical Oxygen Demand \\
Total Oil \& Grease \\
Chloride \\
\hline
\end{tabular}


WHC-SD-WM-DQO-024 Rev. 0

This page intentionally left blank. 
WHC-SD-WM-DQO-024 Rev. 0

\subsection{DECISION ERROR LIMITS}

Per the TWRS DQO Procedures (Banning 1996), decision error limits which define acceptable levels of error for measurement data are to be discussed in this section. However, the regulations do not mandate any specified decision errors, therefore no decision error limits for any TWRS permitted direct discharges of wastewater are addressed in this document. 
WHC-SD-WM-DQO-024 Rev. 0

This page intentionally left blank. 


\subsection{OPTIMIZATION OF SAMPLING AND ANALYSIS DESIGNS}

The sampling and analysis as required by design is optimized using data from Section 6.0. Section 8.0 provides criteria for the number of samples to be taken and the sampling and analysis methods. Optimization may be implemented in a sampling and analysis plan, interface control document, waste acceptance plan, or other sampling document.

The requirements for sampling/analysis of discharges, can be outlined in the permit issued by Ecology. Other sampling/analysis requirements may be outlined by documentation formulated by a wastewater treatment or storage facility that the streams are discharged to. If neither of these documents requires any sampling/analysis protocol, then the following criteria can be used to optimize sampling/analysis events.

\subsection{NUMBER OF SAMPLES}

If a permit for an effluent specifies a sampling frequency then that frequency must be followed. In the absence of a specified sampling frequency, a minimum of two samples should be collected. This would be a best management practice and help prevent an anomaly in analytical results. If analytical results do not correspond to estimated quantities or previous results, additional sampling or analyses may be required to predict conformity of the waste stream.

\subsection{SAMPLING AND ANALYSIS METHODS}

All analyses should be conducted according to agency-approved procedures such as those contained in 40 CFR Part 136. The use of registered or accredited laboratories is required for preparation of data submitted to Ecology in support of state permits (WAC 173-216-125). The Environmental Cleanup and Compliance Project should approve deviations from agency approved methods. The following subsections describe sample handling and analysis methods which should be used provided that all specified analytes are detected, or concurrence is obtained from Environmental Cleanup and Compliance Project.

\subsubsection{Sample Handling and Analysis}

All samples must be handled and transported to the laboratory in a manner to ensure that the integrity of the samples will be protected. All sample handling documentation must be confirmed by the sampling laboratory. Packaging and shipping requirements are specified in Section E II 5.1, of the Environmental Investigations and Site Characterization Manual (WHC 1989). 
Traceability of samples obtained during the sampling activity must be controlled as specified in the latest revision of the Quality Assurance Project Plan (QAPP). A chain-of-custody form must be filled out for the samples at the time of sampling and must accompany each sample. A sample may consist of several containers and the chain-of-custody must account for each container. Once a sample has been drawn it must be in the physical control or view of the custodian, locked in an area where it can not be tampered with, or prepared for shipping with tamper-proof tape applied. Physical control includes being in the sight of the custodian, being in a room which must signal an alarm when entered, or locked in a cabinet. When more than one person is involved with sampling, one person shall be designated and only that person signs as sample. This person is the custodian until the samples are transferred to another location or group and shall sign when releasing the samples to the designated receiver.

The approved laboratory shall designate a sample custodian and an alternate custodian responsible for receiving all samples. The sample custodian or the alternate shall sign and date all appropriate receiving documents at the time of receipt and at the same time initiate an internal chain-of-custody form using documented procedures.

Analytical procedures and holding times shall use SW-846 or other agency approved procedures. When an effluent is sent to a receiving facility, the analytical requirements must follow the requirements of that facility.

The constituents to be analyzed are listed in Table A-1. Quality assurance objectives including the analytical method, precision, accuracy, and completeness, unless otherwise stated, shall be detailed in the QAPP. These criteria may be adjusted by agreement with the proposed laboratory prior to final approval of the contract or work order.

\subsubsection{Detection Limits}

Detection limits may be specified in the individual or categorical 216/218 state waste discharge permits issued by Ecology. Otherwise, detection limits for analytes listed in Table A-1 must be less than the specific quantification limits contained in WAC 173-200 and 40 CFR 372.

\subsection{QA/QC SAMPLES}

All Quality Assurance/Quality Control (QA/QC) samples must be collected at the same time that actual samples are collected. The sampling of the wastewater will include at least one set of duplicate samples. A set of QA/QC samples must accompany an actual chemical sample to the respective laboratory. 


\subsubsection{Trip Blanks}

The trip blank shall be analyzed at the laboratory as if it were an actual sample. The sample collection bottle shall be filled in a manner consistent with sampling protocol. The filled bottle shall travel with the bottle designated for sample collection. The trip blank bottle(s) shall be labeled in the same manner as the actual samples, but shall have a unique sample numbers.

\subsubsection{Duplicate Samples}

At least one duplicate sample shall be collected for every 20 actual samples (or every 5 percent of the time) at a minimum.

A duplicate sample will be collected at the same time and from the same homogenized mixture that an actual sample is collected. The duplicate shall be analyzed for the same constituents as the actual sample that it represents. The duplicate sample bottles shall be labeled identically to the actual sample, but will be assigned a unique sample number.

\subsubsection{Equipment Blanks}

Equipment blanks shall be collected at the same time duplicate samples are collected. The equipment blank is to be collected to represent the conditions present during collection of the sample. Reverse Osmosis/De-Ionized (RO/DI) water shall be used to mimic collection of the sample. The equipment blank shall be analyzed for the same constituents as the actual sample that it represents.

The equipment blank sample bottles shall be labeled identically to the actual sample, but will be assigned a unique sample number. This information shall not be indicated on the label, the chain of custody or any other documents that accompany the sample to the laboratory. 
WHC-SD-WM-DQO-024 Rev, 0

This page intentionally left blank. 


\subsection{REFERENCES}

40 CFR 372, 1988, "Toxic Chemical Release Reporting: Community Right To Know," Code of Federal Regulations, as amended.

Banning, D. L., 1996, Data Quality Objectives Procedure, WHC-IP-1216, Rev. 1, Westinghouse Hanford Company, Richland, Washington.

DOE, 1995, Inventory of Miscellaneous Streams, DOE/RL-95-82, Revision 0, U.S. Department of Energy, Richland, Washington.

DOE, 1994, Plan and Schedule for Disposition and Regulatory Compliance for Miscellaneous Streams, DOE/RL-93-94, Revision 1, U.S. Department of Energy, Richland, Washington.

Ecology, 1995a, State Waste Discharge Permit No. 4502 for the 200 Area Treated Effluent Disposal Facility, State of Washington Department of Ecology, April 18, 1995.

Ecology, 1995b, State Waste Discharge Permit No. 4500 for the 200 Area Effluent Treatment Facility, State of Washington Department of Ecology, June 26, 1995.

Ecology and USDOE, 1991, Consent Order No. DE 9INM-177, Washington State Department of Ecology, U.S. Department of Energy, Olympia, Washington.

Emergency Planning And Community Right-To-Know Act Of 1986, 42 USC 1100, et seq.

EPA, 1994, Guidance for the Data Quality Objectives Process, EPA QA/G04, U.S. Environmental Protection Agency, Washington, D.C.

WAC 173-200, "Water Quality Standards for Ground Waters of the State of Washington," Washington Administrative Code, as amended.

WAC 173-216, "State Waste Discharge Permit Program," Washington Administrative Code, as amended.

WAC 173-218, "Underground Injection Control Program," Washington Administrative Code, as amended.

WHC, 1994, 200 Area TEDF Interface Control Document, WHC-SD-WO49H-ICD-001 Rev.1, Westinghouse Hanford Company, Richland, Washington.

WHC, 1992, Environmental Investigations and Site Characterization Manual, WHC-CM-707, Westinghouse Hanford Company, Richland, Washington. 
WHC-SD-WM-DQO-024 Rev. 0

This page intentionally left blank. 
WHC-SD-WM-DQO-024 Rev. 0

APPENDIX A

REGULATORY DRIVERS OF POTENTIAL DISCHARGES

A-1 
WHC-SD-WM-DQO-024 Rev. 0

This page intentionally left blank.

A-2 


\section{APPENDIX A REGULATORY DRIVERS OF POTENTIAL DISCHARGES}

Table A-1. Regulatory Drivers of Potential Wastewater Discharges. (6 sheets)

\begin{tabular}{|c|c|c|c|}
\hline ) & 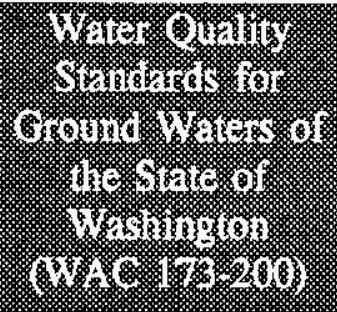 & 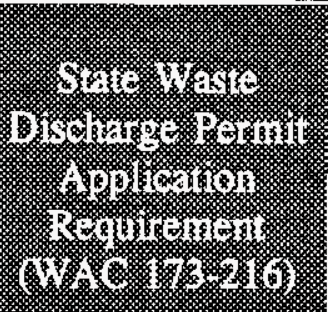 & 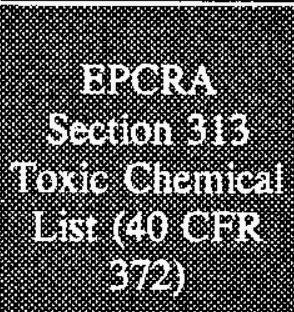 \\
\hline $\mathrm{pH}$ & * & * & \\
\hline Conductivity & & * & \\
\hline Total dissolved solids & * & * & \\
\hline Total suspended solids & & * & \\
\hline BOD (5 Day) & & * & \\
\hline COD & * & * & \\
\hline Ammonia-N & & * & * \\
\hline TKN-N & & * & \\
\hline Nitrate-N & * & * & \\
\hline Ortho-phosphate-P & & * & \\
\hline Total-phosphate-P & & * & \\
\hline Total oil and grease & & * & \\
\hline Calcium & & * & \\
\hline Magnesium & & * & \\
\hline Sodium & & * & \\
\hline Potassium & & * & \\
\hline Chloride & * & * & \\
\hline Sulfate & * & * & \\
\hline Flouride & * & * & \\
\hline Cadmium (total) & * & * & * \\
\hline Chromium (total) & * & * & * \\
\hline Lead (total) & * & * & * \\
\hline
\end{tabular}


Table A-1. Regulatory Drivers of Potential Wastewater Discharges. (6 sheets)

\begin{tabular}{|c|c|c|c|}
\hline (I) & 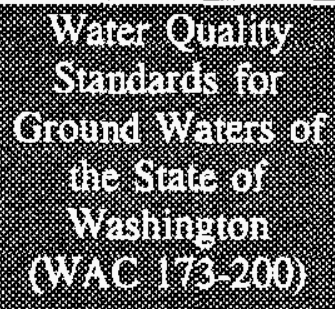 & 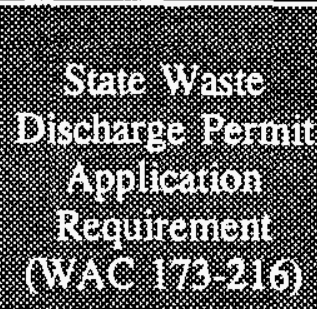 & 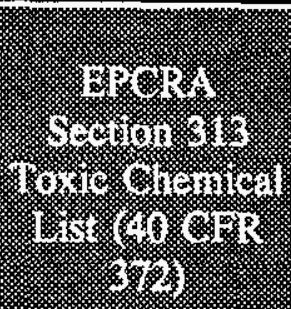 \\
\hline Mercury & * & $*$ & * \\
\hline Selenium (total) & * & * & * \\
\hline Silver (total) & * & * & \\
\hline Copper (total) & * & * & * \\
\hline Iron (total) & * & * & \\
\hline Manganese (total) & * & * & * \\
\hline Zinc (total) & * & * & * \\
\hline Barium (total) & * & * & * \\
\hline Total Coliform & * & * & \\
\hline Acrylamide & * & * & * \\
\hline Acrylonitrile & * & * & * \\
\hline Aldrin & * & * & * \\
\hline Aniline & * & * & * \\
\hline Aramite & * & * & \\
\hline Arsenic & * & * & \\
\hline Azobenzene & * & * & \\
\hline Benzene & * & * & * \\
\hline Benzidine & * & * & * \\
\hline Benzo(a)pyrene & * & * & \\
\hline Benzotrichloride & * & * & * \\
\hline Benzyl chloride & * & * & * \\
\hline Bis(chloroethyl)ether & * & * & \\
\hline Bis(chloromethyl)ether & * & * & * \\
\hline $\begin{array}{l}\text { Bis(2-ethylhexyl) } \\
\text { phthalate }\end{array}$ & * & * & \\
\hline
\end{tabular}


WHC-SD-WM-DQO-024 Rev. 0

Table A-1. Regulatory Drivers of Potential Wastewater Discharges. (6 sheets)

\begin{tabular}{|c|c|c|c|}
\hline ing. & 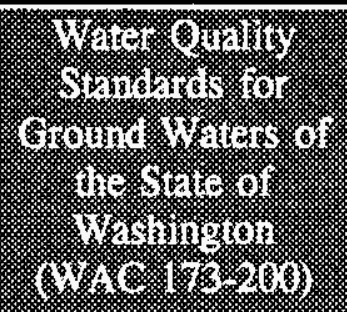 & 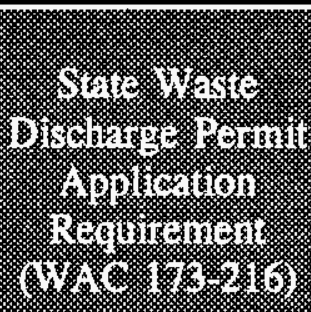 & 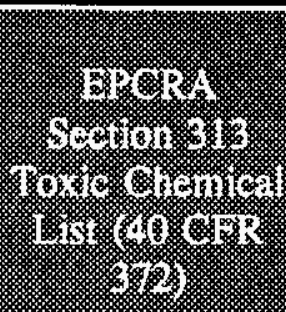 \\
\hline Bromodichloromethane & * & * & \\
\hline Bromoform & * & * & * \\
\hline Carbazole & * & * & \\
\hline Carbon Tetrachloride & * & * & * \\
\hline Chlordane & * & * & * \\
\hline Chlorodibromomethane & * & * & \\
\hline Chloroform & * & * & * \\
\hline Chlorthalonil & * & * & * \\
\hline 1,2 Dichloropropane & * & $*$ & * \\
\hline 1,3 Dichloropropene & * & * & \\
\hline Dichlorvos & * & * & * \\
\hline Dieldrin & * & * & \\
\hline 3,3 Dimethoxybenzidine & * & * & * \\
\hline 3,3 Dimethylbenzidine & * & * & * \\
\hline 1,2 Dimethylhydrazine & * & * & \\
\hline 2,4 Dinitrotoluene & * & * & * \\
\hline 2,6 Dinitrotoluene & * & * & * \\
\hline 1,4 Dioxane & $*$ & * & * \\
\hline 1,2 Diphenylhydrazine & * & $*$ & * \\
\hline 2,4-D & * & * & * \\
\hline DDT & * & $*$ & \\
\hline Diallate & * & * & * \\
\hline 1,2 Dibromoethane & * & * & * \\
\hline 1,4 Dichlorobenzene & * & * & * \\
\hline
\end{tabular}




\section{9-V}

\begin{tabular}{|c|c|c|c|}
\hline & $*$ & * & XəI!W \\
\hline \multirow[t]{4}{*}{ * } & $*$ & * & 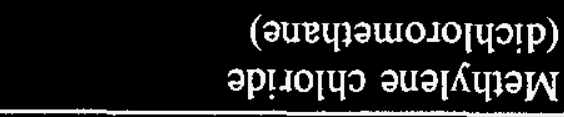 \\
\hline & $*$ & * & 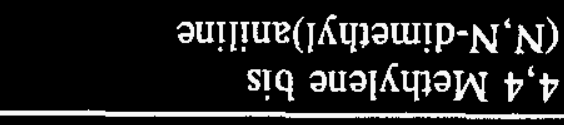 \\
\hline & * & $*$ & 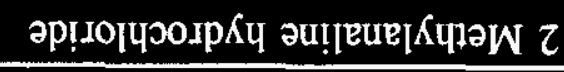 \\
\hline & * & * & วu![Ruе[Кц1әW Z \\
\hline * & * & * & әuвpu! T \\
\hline \multirow[t]{3}{*}{ * } & $*$ & * & 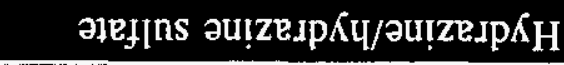 \\
\hline & $*$ & * & u!̣xo!p-d-ozuәq!posо|чәехәН \\
\hline & $*$ & & ('чәә) әивхәцојоКолоцчэехәН \\
\hline * & * & * & 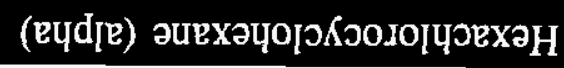 \\
\hline \multirow[t]{2}{*}{ * } & $*$ & * & әนәzuәqолоцчวехәН \\
\hline & $*$ & $*$ & 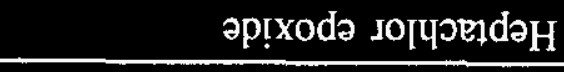 \\
\hline \multirow[t]{2}{*}{ * } & $*$ & * & ІоГцәюฺdәН \\
\hline & $*$ & $*$ & 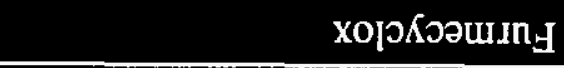 \\
\hline \multirow[t]{3}{*}{$*$} & $*$ & * & $1 \partial d j \mathrm{O}_{\mathrm{H}}$ \\
\hline & * & * & 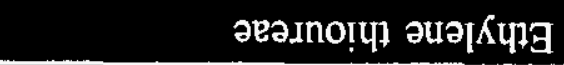 \\
\hline & $*$ & * & 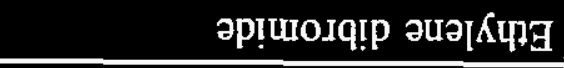 \\
\hline * & $*$ & $*$ & 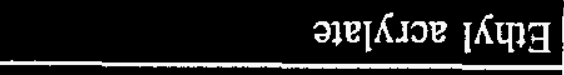 \\
\hline \multirow[t]{2}{*}{ * } & * & $*$ & 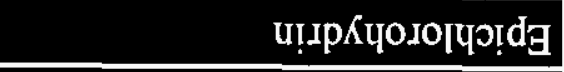 \\
\hline & * & $*$ & ulıpug \\
\hline \multirow[t]{2}{*}{ * } & $*$ & $*$ & әนеч1әодочग! \\
\hline & $*$ & * & 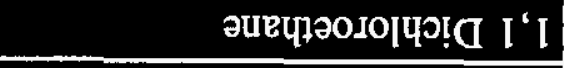 \\
\hline$*$ & $*$ & * & әu!p!zuәqолочग! $\mathcal{E}^{\star} \varepsilon$ \\
\hline 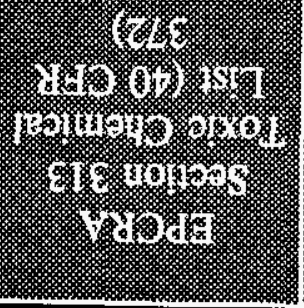 & 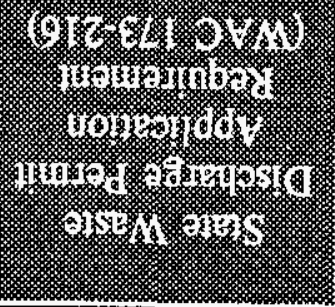 & 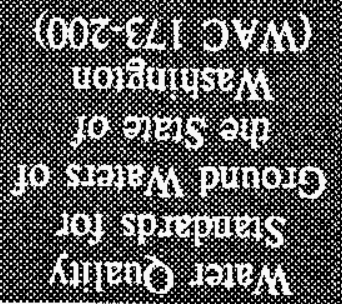 & 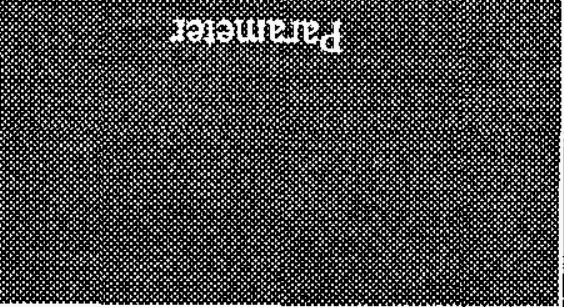 \\
\hline
\end{tabular}

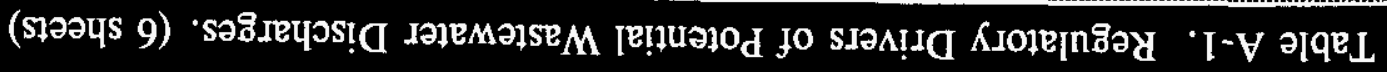


Table A-1. Regulatory Drivers of Potential Wastewater Discharges. (6 sheets)

\begin{tabular}{|c|c|c|c|}
\hline II & 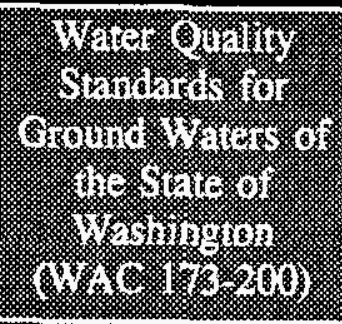 & 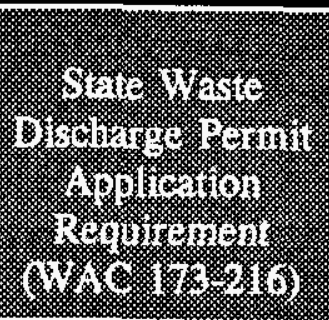 & 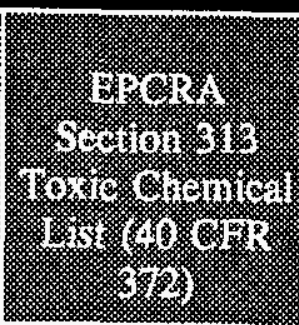 \\
\hline Nitrofurazone & * & * & \\
\hline $\mathrm{N}$-nitrosodiethanolamine & * & * & \\
\hline $\mathrm{N}$-nitrosodiethylamine & * & * & * \\
\hline $\mathrm{N}$-nitrosodimethylamine & * & * & * \\
\hline $\mathrm{N}$-nitrosodiphenylamine & * & * & * \\
\hline $\mathrm{N}$-nitroso-di-n-propylamine & * & * & * \\
\hline $\mathrm{N}$-nitrosopyrrolidine & $*$ & * & \\
\hline $\mathrm{N}$-nitroso-di-n-butylamine & * & * & * \\
\hline $\mathrm{N}$-nitroso-n-methylethylamine & * & * & \\
\hline PAH & $*$ & * & \\
\hline PBBs & * & * & \\
\hline PCBs & * & * & * \\
\hline O-phenylenediamine & $*$ & * & \\
\hline Propylene oxide & * & * & \\
\hline $\begin{array}{l}\text { 2,3,7,8-Tetrachlorodibenzo-p- } \\
\text { dioxin }\end{array}$ & * & * & \\
\hline Tetrachloroethylene & $*$ & * & * \\
\hline 2,4 Toluenediamine & * & * & \\
\hline o-Toluidine & * & * & * \\
\hline Toxaphene & * & * & * \\
\hline Trichloroethylene & * & * & * \\
\hline 2,4,6-Trichlorophenol & * & * & * \\
\hline Trimethyl phosphate & * & * & \\
\hline Vinyl chloride & * & * & * \\
\hline
\end{tabular}


Table A-1. Regulatory Drivers of Potential Wastewater Discharges. (6 sheets)

\begin{tabular}{|c|c|c|c|}
\hline I & 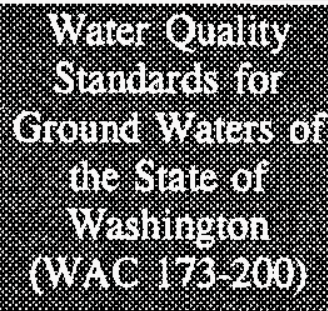 & 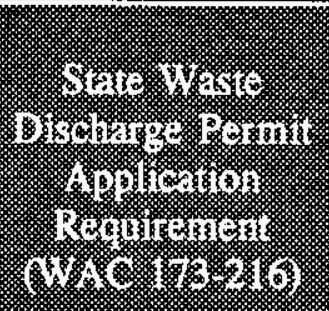 & 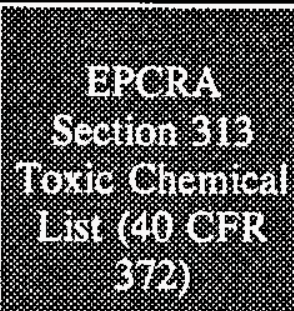 \\
\hline $\begin{aligned} \text { Radionuclides } & \\
\sim & \text { Gross Alpha } \\
& \text { Gross Beta } \\
& \text { Tritium } \\
& \text { Strontium-90 } \\
& \text { Radium } 226 \text { \& } 228 \\
& \text { Radium }-226\end{aligned}$ & * & & \\
\hline
\end{tabular}

Notes:

* Subject to specified regulation.

- Radionuclides are currently addressed via best management practices established by DOE Orders. DOE Orders pertaining to controlling radionuclide releases are pending approval as federal regulations.

Radionuclide effluent limits were adopted from WAC 173-200 in accordance with the TEDF state waste discharge permit (Ecology 1995a).

Applicable references:

1. Liquid Effluent Study Characterization Data, WHC-EP-0355, Westinghouse Hanford Company, 5/90

2. Liquid Effluent Study Final Project Report, WHC-EP-0367, Westinghouse Hanford Company, 8/90

3. Waste Stream Characterization Report, WHC-EP-0287, Westinghouse Hanford Company, 8/89

4. 200 Area TEDF State Waste Discharge Permit Application, 8/94 and Interface Control Document, 11/94

5. 200 Area ETF State Waste Discharge Permit Application 